\title{
The Theory and Rhetoric of Liberty in Spinoza's Political Philosophy
}

\section{Larry W. Chappell}

\section{Introduction}

Benedict Spinoza is widely regarded as a major figure in the history of philosophy and a minor figure in the history of political philosophy. This judgement has merit. Spinoza's political writings do not approach his Ethics in originality, penetration or influence; nor do they compare well with the writings of the great political philosophers. Nevertheless, Spinoza's political writings reveal keen insights into problems of liberal thought. His contribution to liberal thought involves attempt to reconcile a Hobbesian conception of authority and an apparent commitment to a wide range of civil liberties.

"Apparent" is a necessary qualification. Spinoza's praise of civil liberties could be interpreted as part of the general pattern of dissimulation Leo Strauss detects in his writings. 1 At the conclusion of the Theolgico-Political Treatise, Spinoza volunteers to retract anything the authorities "decide to be repugnant to the laws or prejudicial to the public good" ( $T r$. XX, p. 266). 2 Spinoza's panegyrics on liberty may be nothing more than flattery for his adopted homeland, for a people who prided themselves on the love of liberty. The merits of this speculation are difficult to determine. Spinoza appeared sincere enough in his republican politics-assuredly sincere in his love for his republican friends. 3 I shall suggest, however, that a partial dissimulation is involved-that Spinoza's defense of freedom is real, but more restricted than appears at first sight.

I shall maintain three basic theses concerning Spinoza's treatment of liberty. First, Spinoza sustains a creative ambiguity about "natural rights." On the one hand, he argues that a social contract requires that natural rights be given up in civil society. On the other hand, he argues, that they are and should be retained. The apparent contradiction is resolved when we consider that the social contract has both a theoretical and a rhetorical function in Spinoza's thought. Social contract doctrine is addressed to an audience that is expected to accept it (at least sometimes). The expectation that it will be accepted is partially independent of its truth or rationality. Social contract theory is useful for securing public and private advantages.

Second, there are two defenses of civil liberty in Spinoza's political writings-one for the philosopher, another for the "vulgar." Spinoza's arguments sometimes justify a circumspect grant of liberties by a 


\section{Spinoza's Political Philosophy}

sovereign to the populace for the sake of civil concord. Other arguments reassure sovereigns of the public utility of speculative freedom for philosophers.

Third, Spinoza's defense of civil and natural rights is primarily concerned with the liberty of the few, particularly philosophers. As Stanley Rosen observes, Spinoza is not a "modern liberal"; true freedom is presumed to belong only to the philosophers (1973). The conviction, highlighted in the Constitution of the United States, that government should secure liberty "for all" is foreign to Spinoza's way of thinking.

\section{Are Natural Rights Retained in Civil Society?}

Spinoza's affirmation of liberty is set in the context of a vigorous assertion of the need for strong, indeed unlimited public authority. Chapter XVI of the Theologico-Political Treatise and the first four chapters of the Political Treatise read like a paraphrase of Hobbes' Leviathan. The origins of the state are traced to a love of power rooted in man's nature. A pre-social "state of nature" is described in which fear and insecurity reign supreme. Men are described as giving up their liberty, in accordance with the dictates of reason, for the sake of security. Almost all power or "right" (Spinoza, like Hobbes, equates power and rights) are transferred to the sovereign. In civil society, the sovereign has authority to command obedience with few apparent restrictions. With Spinoza's draconian emphasis on the authority of the sovereign, there appears to be little room for the liberty of individuals.

One avenue for discovering a place for freedom seems closed to Spinoza. Locke later attempted to reconcile liberty and authority by maintaining that "natural rights" are retained in civil society-that the transfer of authority to the sovereign from the state of nature is not complete. At first glance, Spinoza seems to accept a thesis of this sort. He argues that no transfer of power to a sovereign could be total.

No one can ever so utterly transfer to another his power and, consequently, his rights, as to cease to be a man; nor can there ever be a power so sovereign that it can carry out every possible wish. (Tr. XVII, p. 214)

There are two separate claims here. The first is that being a man involves rights that are inalienable. This is the natural rights thesis proper. The second claim is that there are prudential limits to what a government can do. I shall return to the latter claim momentarily.

As for natural rights proper, we find nothing so extensive as Locke's catalogue of life, liberty and property. What "inalienable" rights do we possess as men qua men? So far as I can ascertain, Spinoza recognizes one inalienable right (aside from the right of self preservation, which Hobbes also recognizes.). No one can compel our inward assent to untruth; therefore, "everyone has an inalienable right over his thoughts" ( $T r$. XVIII, p. 241). To ears attuned to the tradition of Lockean liberalism, this may sound like a bold trumpet. On closer examination, Spinoza is no more "liberal" than Luther who maintained the same thesis. 4 For the liberty of thought retained 
against the sovereign authority to regulate the outward manifestations of thought. For instance, with the regard to religious thought and belief, the expression of these may be strictly regulated:

Religion acquires its force as law solely from the decrees of the sovereign...the rights of religion and the outward observances of piety should be in accordance with the public peace and should, therefore, be determined by the sovereign power alone ( $T r$. XIX, p. 245).

The political significance of our "inalienable" rights is hardly clear. Inward assent has as little relevance for public affairs as the "happiness" of a stoic burning inside the Phalarian Bull. More importantly, when voices are stifled the possibility of forming an inward assent is severely restricted.

The things we associate with civil liberties receive no serious justification from Spinoza as inalienable rights. The sovereign has virtually unrestricted authority to regulate our speech, religion and political participation. Spinoza's justification for civil liberty, if it is to come to all, must be based upon a prudential, pragmatic or utilitarian rationale. Spinoza must tell what freedom is good for. More specifically, he must give us a rationale for the sovereign to restrict its authority-to refrain from alienating very alienable "rights".

While the texts support this conclusion, it must be qualified. We must assess a careful writer's claims with care. What are we to make of Spinoza's claims that natural rights are retained in civil society? While much of the argument is (most probably intentionally) obscure, Spinoza, at times, comes close to claiming that all our rights are retained in civil society.

How could this be? How can a nearly total transfer of rights (power) to a sovereign involve a nearly total retention of rights?

If rights are equated with power, it is quite consistent to transfer actual power while retaining potential power. In other words, it is always a possibility for a people or a person to revoke a grant of authority. It may not be rational to do so, since the revocation would throw us back into the state of nature, but Spinoza is convinced that most people are not rational. They retain their rights even against their interests.

The wise man has a sovereign right to do all that reason dictates or to live according to the laws of reason, so also the ignorant and foolish man has sovereign right to do all that desires dictates, or to live according to the laws of desire (Tr.X VI, p. 201).

Everyone is possessed of continuing rights to whatever is desired and can be taken. Large fish have a right to eat small fish and small have a right to escape. Everything is "in" nature; every impulse is "natural" and right. To condemn the efforts of the "the fool" to fulfill his desires, to expect him to live according to reason, is foolish. The foolish are not expected to live by the "dictates of an enlightened mind" any more than "a cat is expected to live by the laws of a lion" (Tr. XVI, p. 201).

More importantly, rights can be maintained with the appearance to 
the contrary. This is to so because we retain, without asserting, our most inalienable right no matter what-the right to lie. 5 Everyone rationally seeking his own advantage will use whatever appearances seem manipulable and advantageous. The "social contract" is as much a matter of appearance as reality when contracting to form a civil society, everyone must appear sincere.

They must... most firmly decree and establish that they will be guided in everything by reason (which no one will dare openly to repudiate lest he be taken for a madman), and will restrain any desire which is injurious to a man's fellows, that they will do to all as they would be done by, and that they will defend their neighbor's rights as their own (Tr. XVI, p. 203).

The accent has to be on open declaration, for Spinoza almost immediately proclaims that "no one can honestly to forego the right which he has over all things" (Tr. XVI, p. 203). Our adherence to the social compact is guaranteed only be "fear of a greater evil" or "hope of a greater good" (Tr., p. 203). Spinoza is quite clear, then, that allegiance to a government depends on the harm or benefit that it can inflict; "a compact is only made valid by its utility, without which it becomes null and void" (Tr. VXI, p. 204). 6

A rational assessment of a society, therefore, will be based on utility. What can it do for me (to invert President Kennedy's famous statement)? The amount of freedom people should have in civil society is a matter of "right," but a matter of right in two senses. The rights (power) of individuals must be assessed with the right (power) of government. Individually, of course, the question is: What can I get away with in so far as my desires are concerned? The political question is : How much liberty can be granted profitably to my subjects? Thus, the question of natural rights is transformed to an issue of civil rights in political theory.

\section{The Public Utility of Freedom}

Since the time of Bentham and Mill, we have grown accustomed to the simultaneous repudiation of inalienable natural rights and assertion of the merits of freedom.7 Freedom is justified as an instrument necessary for some noble end; e.g., peace, happiness, maturity. Upon whom the blessing of liberty are to be bestowed has been disputed. Is it "the individual" who will benefit? "Society"? All individuals? All societies?

From Spinoza's point of view, the starting point for a political justification of freedom is relatively clear. Freedom involves restrictions upon sovereign prerogative. If one seeks an audience for a petition for liberty, one seeks a dispensation from an unlimited authority limiting its authority.

For Spinoza, like Hobbes, the sovereign is above the law. There are no Constitutional constraints on an unlimited sovereign. The sovereign authors the laws and is not bound by them. There are no principles of right reason to restrain a sovereign either. Moral laws have no binding force. That the sovereign has no moral obligation to recognize "natural rights" does not mean that he must take no notice 
of them. Since natural rights are retained ex potentia, and since the right to lie always poses a threat to sovereign power, the sovereign must calculate the threat posed by his subjects in order to maintain his own power. The liberties of subjects, then, can be justified of the liberties are conducive to the maintenance of sovereign right.

From the sovereign's point of view, civil liberties are not a matter of natural right. They are granted as a dictate of prudence. From the subject's point of view, this is not reassuring. In what ways will the sovereign limit its power? How secure are promises of freedom from an unlimited sovereign?

Spinoza, like Hobbes, recognizes that a promise is made by an unlimited authority is not binding. Promises belong to civil society and the sovereign is above civil society. There can be no "rights" against an absolute sovereign-even rights ostensibly granted by the sovereign. In this sense, "civil liberties" are pure fiction (Tr. Pol., IV).

As mentioned earlier, Spinoza stresses the inability of the sovereign to "carry out every possible wish." Unfortunately, a general counsel to prudence does little to restrict sovereignty. Most rulers are aware that they cannot wish their subjects into unaided flying, but rulers have little trouble finding more realistic orders to issue. Furthermore, the limits to wishing provide no restrictions on what rulers will try. Finding rulers willing to order their subjects to fly is not that difficult to imagine.

In order to find room for freedom, Spinoza must ground the counsel of prudence in some specific aim at the foundation of the state: Government is instituted for the sake of peace.

Spinoza concludes that prudence requires governments to grant liberty to those over whom it has dominion for the sake of peace. The ruler must face the inherent limits of government. He also must be aware of the of the probability that harsh rule will disturb the peace. If a ruler deprives subjects of all liberty enmity will ensue. Indeed,

men have never so far ceded their power as to cease to be an object of fear to rulers who received such power and right; and dominions have always been in as much danger from their own subjects as from external enemies ( $T r$. XVII, p. 214).

Spinoza carries this argument one step further contending (as the Federalist was later to do) that sovereign power can be strengthened through liberty. Various factions can be pitted against one another (especially religious factions) to defuse private power at the expense of public power. Granting freedom of speech to the various groups is particularly useful for this purpose (Tr. XX, pp. 259-264). This is an interesting argument, but one requiring serious qualification. Spinoza is well aware that there have been rulers who have pushed the limits of oppression. He admits the possibility of a lasting "tyranny" and even provides us an example-the Turkish Empire.

Spinoza's counter-example demands modification, not necessarily abandonment, of the thesis that harsh rule endangers peace. Spinoza suggests that people who are accustomed to liberty will not willingly and continually submit to a tyrant: "It is exceedingly difficult to revoke liberties once granted" (Tr. V, p. 74). even if this is conceded a 
theoretical void is left: Why are some peoples granted liberties while others are not? This void would be filled, as liberal doctrines became more commonplace, in a variety of ways-ranging from Calhoun's's notion that some people need tutelege to prepare for liberty, to racist theories that claim a genetic basis for freedom.

In any event, the thesis is questionable. The possibility of short or long term tyranny over a free people is a real concern. More importantly, a purely negative thesis of the sort we have been discussing reveals little of the purported blessings of liberty. To say that liberty is difficult to destroy may lead to caution among would be tyrants; it offers little incentive for a free people to struggle to defend its liberties. A more positive defense of liberty is needed.

\section{Liberty for the Few}

Spinoza does not rest content with Machiavellian cautions to would be tyrants. He boldly insists on a broader utility for freedom. Indeed, he is so bold as to assert that "the true aim of government is liberty" (Tr. XX, p. 259). If government comes into being for the sake of peace, how can its true aim be liberty? Spinoza argues that mere security from violence does not exhaust the meaning of peace and that a commonwealth is built upon more than the mere absence of violence.

Peace is not mere absence of war, but is a virtue that springs from force of character: For obedience is the constant will to execute what, by the general decree of the commonwealth ought to be done. Besides, that commonwealth, whose peace depends on the sluggishness of its subjects, that are led about like sheep to learn but slavery, may more properly be called a desert than a commonwealth (Tr.., V, sec. 4).

This passage is perplexing because Spinoza, like Hobbes, founds the state upon a transfer of power or right (which are equated), to an unrestricted sovereign. What is our common-wealth if not our common security from one another? As Leo Strauss has noted, Hobbes and Spinoza proceed with different conceptions of "Power" (1965, p. 238). For Hobbes, power is nothing more than the ability to get what one desires. Since our desires include things that others desire (even their bodies), conflict is inevitable. The struggle for power in Hobbes is essentially a zero-sum game (Lev., Chap VI).

Spinoza's conception of power is multi-tiered. It includes Hobbes' meaning, but involves more. Power not only involves struggle, but cooperation as well. Power is additive; "the more there are that combine together, the more right they collectively possess" ( $\mathrm{Tr}$. Pol., II, sec. 15). This entails the trivial point that two people chopping a tree will be more effective than one. At this level, it is open to the obvious objection that pharaohs sweat less when they have slaves building pyramids rather than when pitching in themselves.

Spinoza's thesis is not trivial, and it is arguably true. Co-operative power is based on willing assent. Liberty provides the opportunity to turn a desert into an oasis. Freedom can increase our common-wealth.

We have not yet reached the apex of Spinoza's conception of 
power. Power, for him, is not merely having or doing, but also being. As Lovejoy rightly observes, Spinoza fits squarely in the tradition of philosophers affirming the "great chain of being" (1964, pp. 105-56). For Spinoza, power involves the capacity to realize our essence. What we are is our effort to be. "The effort (conatus) by which a thing endeavors to persevere in its own being is nothing but the actual essence of the thing itself" (Eth. III, Prop. VIII). Men and women can attempt to persevere in the way that Hobbes describes. They may also seek to live in a more "blessed" state-to live a life of "reason."

Spinoza's use of the term reason highlights the differences between his vision of human possibility and that of Hobbes. For Hobbes, reason is strictly instrumental; it provides the means to achieve those ends prompted by our desires and needs. Spinoza accept this sense of reason but includes something more. For him, reason can guide us to an understanding of "eternal truths."

Attuning ourselves to these eternal truths is the highest aim we can have and provides the greatest happiness we can attain. In short, Spinoza has retained something of the classic vision of reason as a pathway to a summum bonum. Hobbes has abandoned the summum bonum altogether (Strauss, 1965, pp. 244-45; Voegelin, 1952, pp. 17887).

What the retention of the summum bonum means, in political terms, is not immediately clear. 8 Only a few are expected to reach the state of blessedness attained through an intellectual love of God. For most people, attainment of the life of reason is not possible. Furthermore, reason provides no basis for instructing the "vulgar" in the requirements of the good life. Those incapable reason have a right to their unreason. Someone possessed of reason, however, can guide the vulgar indirectly. Political instruction by a "reasonable" person is a rhetorical process with requirements distinct from the rigors of philosophical comprehension. The process of persuasion also accords with the purposes of the man of reason-it must allow him to persevere in his being.

Regardless of the ambiguities in Spinoza's conception of power, he has established the basis for two additional justifications for freedom (both of which can, be found among John Stuart Mill's arguments). Freedom of thought is necessary for a) the good of the commonwealth and $\mathrm{b}$ ) the good of the individual.

The commonwealth benefits because freedom allows the cultivation of science.

Freedom is absolutely necessary for progress in science and liberal arts: For no man follows such pursuits to advantage unless his judgment be entirely free and unbampered. (Tr., XX, p. 261)

Spinoza did not have the opportunity to witness the full fruits of modern science, its blessings or its perils, but the strain of optimism about science running from Bacon through the nineteenth century has its refrain here. He does not elaborate his point, but clearly feels that the arts and sciences benefit the commonwealth and that freedom is their prerequisite.

The greatest benefits of freedom accrue to the individual. Not just 
any individual. The greatest fruits of liberty are granted to homo philosophicus. Who besides the philosopher has attained to that rare and difficult nobility the praise of which concludes the Ethics? The concern for speculative freedom has its pragmatic dimension in Spinoza: "Laws dealing with speculative problems are entirely useless" (Fr., XX, p. 265). But there is a matter of more singular importance at stake. Spinoza is trying to persevere in his own being, and the example of Socrates should convince any philosopher of the perils of politics. Spinoza maintains that "the chief aim" of the TheologicoPolitical Treatise is to "separate faith from philosophy" (Tr., XIV, p. 183). The careful reader of the treatise can have little doubt concerning which party is expected to benefit from the divorce. In any event, it is not clear what benefits the commonwealth is expected to derive from the lonely pleasures of philosophy-a point to which I shall return.

\section{Evaluating Spinoza's Defense of Liberty}

What are we to make of Spinoza's defense of liberty? Whatever we decide, the questions he raises have s distinct bearing on the problems facing 20th century liberalism. Our faith in inalienable rights of man has been dimmed. A wide range of political movements have arisen which reject the purported blessings of liberty. Time and again we have seen the use of freedom to undermine the conditions of freedom (Fromm, 1941). How much reassurance does Spinoza provide in the struggle to preserve our fundamental liberties?

I contend that Spinoza's arguments, like those of Mill, are plausible as a defense of the few. Their plausibility diminishes to the extent that they are universalized. Spinoza argued that "liberty can be conceded to every man without injury to the rights and authority of sovereign power" (Tr., XX, p. 265). The extension of freedom is not simply safe; unlimited liberty is desirable. "Every man should think what he likes and say what he thinks" (Tr., XX, P. 265).

Spinoza is hardly so sanguine about the benign character of liberty as these quotations would lead us to believe. Take, for instance, the contemporary liberal commitment to religious liberty. A good portion of the Theologico-Political Treatise is devoted to warning of the dangers posed to civil peace by religious schisms. Spinoza is no less alarmed than Hobbes by the threat of civil war over religious issues, and he is no less firm in assigning the final word on religious matters to the sovereign (Tr., XIX, pp.252-255). To be sure, Spinoza rejects an established religion (Tr. Pol., Vi, sec. 40). It is no less true that Spinoza advocates a civil religion to which all are expected to give public acceptance (Tr., XIV). At least part of the apparent conflict is resolved by reflecting on the function of civil religion. A civil religion sets a minimum body of belief which all are expected to profess publicly. An established religion, on the other hand, may entail regulation of minute aspects of belief and practice. Civil religion, then, may be quite tolerant of religious diversity in a manner not open to an established religion.

In any event, Spinoza recognizes a legitimate sovereign interest in regulating religious matters extending well beyond 20 th century 
liberal standards for religious freedom? Why?

Many of Spinoza's deepest concerns stem from his distinction between the wise man and the fool-a distinction as sharp as it ever was among the early stoics. The wise are those capable of forming clear and distinct ideas-those suited to scientific or philosophic thought. The fools are those who must think in images, for whom superstition is more likely than science. Unfortunately, the latter are far more numerous than the former. Since the vulgar are unlikely to learn the truth through disciplined reflection, they must learn obedience through the moving images of scripture. Spinoza makes it quite clear who is and who is not bound to the discipline of scriptural revelation:

It is now, I think, sufficiently clear what persons are bound to believe in the scripture narratives, and in what degree they are so bound, for it evidently follows from what has been said that the knowledge of and belief in them is particularly necessary to the masses whose intellect is not capable of receiving things clearly and distinctly $(T r ., V, p .78)$.

Spinoza is much less concerned with the freedom of the masses than those few who are suited for philosophical freedom. Indeed, his primary concern is to restrict the freedom of the rancorous sects which pose a threat to independent speculation. For theologians wrongly claim truth for the scriptures when only obedience is warranted ( $T r .$, XV, pp. 194-195).

Alas, both the fool and the wise man are possessed of an equal "natural right" to such power as is attainable. This poses some serious problems. Spinoza agrees with Hobbes that the dictum "seek peace and follow it" is a rational ordinance for mankind. 9 He, (like Hobbes), does not accept, however, the notion that most men are reasonable. Thus, our political cement must come from some source other than reasoned judgment. Like Hobbes, he found it necessary to rely on the susceptibility of the masses to religious imagery and superstitious instruction in obedience to supplement the ordinance or reason, 10 This does not, as Strauss contended in his book on Spinoza, wreck Spinoza's commitment to freedom; it merely restricts it. The Theologico-Political Treatise with its arguments buttressed by scripture and imagery, may be viewed as a philosopher's contribution to civil theology for the sake of philosophical liberty. 11 The philosopher's reason tells him that he must not disturb the public order, for that provides his succor. He must not arouse the masses, for they will turn upon him with unreasoned passion. He must create a space of freedom where speculation can proceed unhindered. In pursuing this task, he may call upon unphilosophical weapons, for politics is not a realm where reason reigns supreme. Free speech must be granted to all insofar as the public order is not disturbed and so long as the superstitions are not allowed to hinder the free inquiring of the philosopher (Tr., XX, esp. p. 264).

This view seems benefitting for a philosopher seeking to persevere in his being. For those of us who do not attain the ecstasies of contemplation, however, another kind of justification is required. The social benefits of freedom must be defended. Spinoza assures us 
that these benefits will accrue. The benefits of a general grant of freedom (to the populace) derive from its contribution to civil concord. The social benefits of speculative (philosophical, scientific) freedom derive from the artifacts of the freedom. The most important artifact is peace, but additional benefits derive from scientific inquiry as well.

On the connection between civil liberty and civil concord, I have already commented. But to amplify: There have been and continue to be many governments that deny basic civil liberties to their subjects with no apparent threat of civil war. Yes, the Soviet Union did survive until 1984, and Iran has out distanced it in many respects in the interim. It is possible, too, that various sects will, instead of cancelling of moderating one another's views, engage in a continuing struggle for dominance without any side triumphing, as is the case in Northern Ireland. Freedom, used to sustain warfare or to initiate tyranny is not clearly a blessing? 12

In any event, the contribution of freedom to civil concord does not justify the full range of liberties affirmed in liberal thought. If free speech is justified because people feel compelled to utter superstitious beliefs (not because they have anything worth saying), we can dispense with freedom if other means are found to secure peace; e.g., psycho-surgery. We need extend no general freedom to discuss important things in meaningful ways. The justification of a more positive conception of freedom must lie elsewhere. What are the positive social benefits of freedom?

Does our prosperity and well being depend upon freedom? I do not intend to rehash the issues in political economy that pertain to this question, since they have no clear bearing on Spinoza. Of capital importance is the claim, made by Spinoza and reiterated by liberals such as J. S. Mill and George Orwell, that scientific progress requires liberty of inquiry. This is undoubtedly true, but it does not follow that everyone should be free in all respects.

Spinoza was quite convinced that science and philosophy are activities for the few. His judgment, with regard to science, remains essentially correct. The fruits of scientific inquiry grow out of the efforts of relatively few men and woman. The number of "great" scientists is exceedingly small. The number of ordinary scientists is much larger, but small by comparison with the entire population. It could be contended that the freedom to become scientists must be general, but this is misleading. Not everyone has the aptitude, ability, or opportunity to become a scientist when the desire is present.

Even if everyone is free to become a scientist this would not justify unrestricted inquiry for all. First, the freedom to inquire would only be necessary ( in the highest degree) when one became a scientist. Second, the scope of inquiry could be restricted. A biologist has no particular reason to ask questions about politics. If the work has political implications (e.g., work in genetics), there is no reason to share results with the public. The results can be obscured by technicalities and jargon inpenetrable to all but specialists.

Some maintain that any political restriction on scientific activity inevitably destroys the benefits of science. (Polanyi, 1964;1975). Certainly, the Lysenko affair illustrates the dangers of state regulation 
(Medvedev, 1971). On the other hand, there are limits to the freedom that science can rightfully claim (Feyerbend, 1978). To claim an unrestricted "right" to inquire regardless of the demonstrated benefits or ethical propriety of research is to test the limits of political tolerance. When this "right" is conjoined with a demand for public funds, political restrictions seem inevitable.

The most common defense of unrestricted science is the unforseen benefits argument. Someday an unexpected application may yield practical benefits from "pure" research. Since these applications cannot be forseen, the path of inquiry must not be blocked. The argument contains enough truth to be misleading. We may expect a large number of authentic confessions if we torture all suspects for criminal offenses. This does not warrant an unrestricted right to torture.

That someone has a shingle that says "scientist" (or social scientist) does not warrant unrestricted liberty. We may learn quite a bit concerning "motivation" from psychologists who torture small animals (Roszak, 1969, pp. 267-281). Does this in any way restrict our political "right" to inquire into the propriety on fruits of this reasearch? The idea that science is "self-regulating" provides little assurance on this score. In any event, there is nothing to prevent unfettered science from using its freedom to enslave the rest of us. Scientists are no less subject to the lust for power (the need for "rights") than the rest of us. Unrestricted freedom for science has as its basis a naive faith to the contrary.

Aside from the social utility of freedom (which surely should be weighed against the dis-utility of, say, an AIDS epidemic), the more interesting arguments deal with individuals. Spinoza suggests a defense of freedom in terms of the increase in power or being it allows. This line of thought recurs in Mill's assessment of the possibilities for "maturity" that accompany freedom and Abraham Maslow's stress on "self-actualization." In both Mill and Maslow this freedom is tied to the social utility of discovering moral truths for oneself (Maslow, 1968). Here, the stress is on opportunity; there are no guarantees for maturity or self-actualization. Spinoza would agree that freedom is requísite to the kind of higher being attained through philosophy or science. I suppose he would have no problems with letting everyone try their hand so long as the a-political character of the enterprise is respected. A stable polity is the pre-condition for philosophy. If philosophy is understood as the "freedom" to disrupt the public order, the impulse is suicidal. Spinoza would not agree with Mill that free airing of false opinions is a safe path to truth. Philosophy is solitary and difficult, not public and loquacious. In any event, the likely fate of a philosophy in the "market place of ideas" is illustrated by the death of Socrates.

\section{Spinoza and Modern Liberalism}

Spinoza provides a sober reminder to those of us who share in the liberal political tradition that our political order is not beyond basic controversy. Our commitment to freedom is often a matter of smug self-assurance when radical reflection on the meaning and value of 
freedom is needed. In a more pastoral setting, we could perhaps afford complacency. In an age characterized by intense ideological disputes and nihilistic resignation, we cannot afford to feel to secure about our liberties.

Spinoza is refreshing because he is disturbing, and we need to be disturbed (rather than smug or nihilistic) about our freedom. The most disturbing question is the one we seem most sanguine about: Is freedom for everyone? We assume that there are "human" rights-that breathing makes it so. Or, at the very least, we assume that there are civil rights to which all Americans are entitled. Do these rights-or should these rights-belong to everyone? Spinoza provides a startling inegalitarian voice to the liberal chorus.

Of course, the question of the fitness of the people for liberty has been a concern throughout much of the history of liberal thought. Mill, for instance, was most concerned that the people would abuse their political liberties to endanger other, perhaps more basic, liberties (1861). This concern has been reinforced by more recent studies of mass political attitudes (Kornhauser, 1959; Stouffer, 1966). These studies have suggested that the commitment to civil liberties is much stronger among elites than among the greater public. This would seem to confirm Spinoza's suspicions, but it also buttresses Mill's hopes since education (a cornerstone for Mill) correlates well with commitment to civil liberties. Nagging questions remain, however, concerning the limits of this process. Can an entire citizenry be educated for liberty? Mill, unlike Spinoza, based his hopes on a notion of "progress"-continued moral improvement resulting from conscious human effort (Alexander, 1976). Ours is a century in which the 19th century faith in progress has been emasculated by totalitarian terrors. The future of liberty for the greater portion of mankind seems an uncertain prospect.

If we can find a basis for our hopes, we have only met half of the challenge Spinoza poses. What is the "normative" basis for our belief in liberty for all? Why should we make the effort to secure basic liberties for citizens who may not always appreciate the effort. Spinoza's analysis suggests, at best, that liberty is to be secured against the many for the few, albeit with benefits accruing for the many against their wishes. For Spinoza liberty belongs to the few. Are there, contrary to his analysis, grounds for affirming equal liberties?

Contemporary liberalism stresses strong egalitarian themes. Most liberals would reject the notion that liberty is merely a blessing bestowed upon elites. How then is Spinoza to be confronted?

Spinoza represents a number of themes congenial to major strands of liberal thought (although we should avoid reading Spinoza merely for his contribution to liberalism). These themes include:

\section{Methodological Individualism}

Analysis of Society and Politics must begin with the aims and desires of "individuals"; Social realities are aggregates from these individual aims.

\section{Psychological Egoism:}

The basic motivation of individuals is satisfaction of one's desires 
even at the expense of others.

Legal Positivism:

"Laws" are products of sovereign will. That law could have its origin in something other than political decisions (e.g., moral law; right reason) is rejected. "Rights," in civil society, are also products of sovereign will.

\section{Consequentialism}

The merits of an act or rule are to be judged by the consequences resulting from it.

\section{Naturalism:}

Man is "in" nature. Whatever aims or justifications he seeks must be adduced without reference to a transcendent origin or end.

These are major themes in liberal thought, but they hardly exhaust the tradition. One can be "liberal" while rejecting these notions.

It is possible, for instance, to seek justifications for liberalism on a non-naturalistic basis. Dante Germino argues that liberal institutions and practices can be defended by a "theocentric liberalism" that recognizes the authority of a transcendent reality (1967 pp 214-37). Germino explicity affirms the equalitarian character of "the new liberalism" (citing T. H. Green as an ancestor). Unfortunately, the character of this new liberalism remains largely undeveloped. Somehow, it is to be non-ideological liberalism, incapable of "reduction to a simple catechism". It will be "flexible, imaginative and inventive" (p. 236).

None of these hints and anticipations are particularly helpful in answering the questions posed by Spinoza, though they suggest a line of thought, that certainly is worth pursuing. Germino's discussion of "the elitist school" indicates that he would respect the formidable barriers to equal liberty, however.

Whatever the possibilities for a transcendentalist liberalism, the prospect will not appear congenial to many liberals. If nothing else, the "naturalist" strain in liberal thought is powerful component. This does nor preclude denying other aspects of Spinoza's thoughts. There is, for instance, a Kantian stand of liberalism that rejects consequentailism in favor of deontology (Kant, 1970).

Two recent writers, John Rawls (1971) and Ronald Dworkin (1978), have stressed themes that run counter to those in Spinoza. Rawls develops "a theory of justice" that strongly emphasizes equality. He bases his analysis on our "sense of justice" which he explicates through a discussion of an "original position" under a "veil of ignorance." We are provided a fictional metempsychosis, a "social contract" under conditions of ignorance, to select the kind of institutions we would have in embodied existence. When we divorce our notion of institutions from our particular interests, we arrive at the conclusion that

all social values, liberty and opportunity income and wealth, and the bases of self-respect-are to be distributed equally unless an unequal distribution of 


\section{Spinoza's Political Philosophy}

any. or all of these values is to everyone's advantage(p. 62).

Dworkin questions the validity of a "contract" in which people hypothetically enter, but he believes Rawls to have pinpointed our most basic "right" -the right to equality (pp. 150-84). This right is based on human "dignity" -the equal respect to which all are entitled. Our entitlement exists regardless of the consequences (e.g. increases in average social welfare) that are presumed to justify their breach.

Whether or not these notions adequately explicate "our" notions of justice is, of course, open to question. Both Rawls and Dworkin seem to reject notions of justice or natural rights that transcend social custom or, perhaps, biological imperatives (Dworkin, 1978 pp 13859). Other writers are more inclined to credit Lockean assertions of "natural rights" (Nozick, 1974). In any event who is to accept the compelling nature of rights and why our sense of justice is to be heeded remain controversial issues.

To resolve or even discuss the range of issues posed by various patterns of liberal thought is, of course, beyond the scope of the present study. Suffice it to say that the meaning, justification and future of liberty remain live issues. Spinoza disturbs our complacency about the issues.

I believe that Spinoza's gulf between the wise man and fool is dug with too much confidence. He reflects the modern pathos of confusing the love of wisdom with its possession. He raises issues of singular importance, however. We live in an era in need of better reasons for freedom. Or, better stories about it. Or, best yet, old stories told better.

\section{Endnotes}

1. Strauss' major reflections on Spinoza occur in "Spinoza's Critique of Religion and Persecution and the Art of Writing. It is in the latter text that that Strauss argues that Spinoza's writings are written between the lines, as it were, to befuddle the ignorant and enlighten the learned. Surely Strauss is correct that we should not accept all of Spinoza's statements at face value. Strauss, at times, overstates his case, however. If we are to accept his suggestions that "God" is a word Spinoza uses with intent to dissimulate, we have some serious issues to traverse. Is there an unequivocal, generally accepted meaning to the term? Why is Spinoza's meaning unacceptable even if untraditional? That there is an obvious meaning being violated is far from obvious.

2. The citations for the Theologico-Political Treatise and the Political Treatise(Tr. and $\operatorname{Tr}$. Pol. respectively are from Benedict Spinoza, A Theologico-Political Treatise and a Political Treatise, trans. R.H.M. Elwes (New York: Dover Books, 1951). Page numbers for the Theologico Political Treatise refer to this edition. Section numbers are given for the Political Treatise. Citations from Spinoza's Ethics are from the edition edited by James Guitmann (New York: Hafner Press, 1949).

3. Spinoza's indignation over the killing of his republican friends, the Dewitts, is relevant. See R.H.M. Elwes introduction to the Theologico Political Treatise and Political Treatise (pp. xvii - xix). 

72.)

10. On Hobbes use of religious imagery and argument see Eisenach (1981, pp. 13-

11. For a discussion of the role of civil theology in politics see Voegelin, 1952, pp. 76-106; and Bellah, 1975.

12. See Gildin $(1962 ; 1969)$ for a good discussion if this issue.

\section{References}

Alexander, Edward (1976). "The Principles of Permanence and Progression in the Thought of J.S.Mill." In James and John Stuart Mill: Papers on the Centenary Conference, pp. 126- 42. Edited by John M. Robson and Michael Laine. Toronto: University of Toronto Press.

Bayle, Pierre (1965). Historical and Critical Dictionary: Selections. Translated by Richard H. Popkin. Indianapolis: Bobbs-Merrill.

Bellah, Robert N. (1975). The Broken Convenant: American Civil Religion in Time of Trial. New York: Seabury.

Dworkin, Ronald (1978). Taking Rights Seriously. Second Edition. Cambridge, Mass.: Harvard University Press.

Eisenach, Eldon J. (1981). Two Worlds of Liberalism. Chicago: The University Press.

Feyerebend, Paul (1982). Science in a Free Society. London: Verso.

Fromm, Erich (1941). Escape from Freedom. New York: Rinehart.

Germino, Dante (1967). Beyond Ideology: The Revival of Political Theory. Chicago: The University Press.

Gildin, Hilail (1962). The Problem of Political Liberty in Mill and Spinoza. Unpublished doctoral dissertation, University of Chicago.

Gildin, Halail, (1969). "Spinoza and the Political Problem." In Spinoza: A Collection of Critical Essays, pp. 375- 387. Edited by Marjorie Grene. Garden City: Anchor.

Green, T.H. (1986). Lectures on the Principles of Political Obligation and Other Writings. Edited by Paul Harris and John Morrow, Cambridge: The University Press

Hallowell, John H. (1950), Main Currents in Modern Political Thought. New York: Henry Holt.

Hume, David (1953). Political Essays. Edited by Charles W. Hendel. Indianapolis: Bobbs-Merrill. 
Kant, Imanuel (1970). Kant's Political Writings. Edited by Hans Reiss. Translated by H.B. Nisbet. Cambridge: The University Press.

Kornhauser, William (1959). The Politics of Mass Society. Glencoe: Free Press.

Lovejoy, Arthur O. (1964). The Great Chain of Being. Cambridge, Mass.: Harvard University Press.

Luther, Martin (1969). "Secular authority: To What Extent Must it Be Obeyed." In Great Political Thinkers: Plato to Present, 4th edition, pp. 309-21. Edited by William Edbenstein. New York: Holt Rinehart and Winston.

Maslow, Abraham (1968). Toward a Psychology of Being New York: Litton, 1968.

Medvedev, Zhores A. (1971). The Rise and Fall of T.D. Lysenko. Translated by Michael Lerner. Garden City: Anchor.

Mill, John Stuart (1861). Considerations on Representative Government. London: Parker, Son and Bourn.

Mill, John Stuart (1962). Utilitarianism, On Liberty, Essay on Bentham. Edited by Mary Warnock. Cleavland: World Publishing.

Nozick, Robert (1974). Anarchy, State, and Utopia. New York: Basic Books.

Polanyi, Michael (1964). Science, Faith, and Society. Chicago: The University Press.

Polanyi, Michael (1975). The Contempt of Freedom. New York: Arno.

Rawls, John (1971). A Theory of Justice. Cambridge, Mass: Belknap.

Rosen, Stanley (1973). "Benedict Spinoza". In History of Political Philosophy, 2nd edition, pp. 431-50. Edited by Leo Strauss and Joseph Cropsey. Chicago: The University Press.

Roszak, Theodore (1969). The Making of a Counter Culture. Garden City: Anchor.

Spencer, Herbert (1981). The Man Versus the State: With Six Essays on Government, Society, and Freedom. Indianapolis: Liberty Classics.

Stouffer, Samuel A. (1966). Communism, Conformity and Civil Liberties. New York: Wiley.

Strauss, Leo (1952). Persecution and the Art of Writing. Glencoe, Illinois: Free Press.

Strauss, Leo (1965). Spinoza's Critique of Religion. New York: Schocken Books.

Voegelin, Eric (1952). The New Science of Politics. Chicago: The University Press.

Voegelin, Eric (1957), Order and History, III. Baton Rouge: Louisiana State and University Press. 